\title{
Natural Regeneration in a Conservation Unit: Subsidy for Restoration Actions
}

\author{
Ana Paula Moreira Rovedder ${ }^{1}$ (D), Roselene Marostega Felker ${ }^{1}$ (D), \\ Rafaela Badinelli Hummel ${ }^{1}$ (D), Bruna Balestrin Piaia ${ }^{1}$ (D), \\ Maureen de Moraes Stefanello ${ }^{1}$ (D), José Carlos Corrêa da Silva Junior ${ }^{1}$ (D), \\ Marcela Peuckert Kamphorst Leal da Silva ${ }^{1}$ (D) \\ ${ }^{1}$ Universidade Federal de Santa Maria - UFSM, Santa Maria/RS, Brasil
}

\begin{abstract}
In order to evaluate the regeneration of a forest remnant, we installed $2562 \times 2 \mathrm{~m}$ plots for measuring forest species individuals with height $\geq 30 \mathrm{~cm}$ and stem diameter $\leq 1 \mathrm{~cm}$. Horizontal structure was evaluated and calculated by the Shannon ( $\left.\mathrm{H}^{\prime}\right)$ diversity index and the Pielou (J) evenness index. We performed clustering analysis by the agglomerative and divisive hierarchical method (the variable was the number of individuals); and used the Principal Component Analysis to verify the species distribution. We sampled 3021 individuals, distributed in 26 families and 51 species $\left(H^{\prime}=2.78\right.$ and $\left.J=0.66\right)$. Allophylus edulis had the highest values of absolute frequency (63.3) and absolute density (5186 ind.ha-1), while Ligustrum lucidum presented greater dissimilarity. The analysis showed the presence of regeneration mechanisms, and evidenced biological invasion problem.
\end{abstract}

Keywords: exotic species, indicator species, multivariate analysis. 


\section{INTRODUCTION}

Seasonal Forest, a forest typology from Rio Grande do Sul (RS), is the most threatened and least protected phytophysiognomy of the Atlantic Forest Biome (SOSMata Atlântica \& INPE, 2015) and therefore, requires more urgent conservation actions. The seasonal forest in RS is located in the upper and middle part of the Uruguay River, in most of the southern slope of Serra Geral, and in dispersed areas around the Ijuí, Jacuí and Ibicuí rivers. This typology occurs as forest disjunctions presenting deciduous stratum (IBGE, 2012).

Information on forest types are necessary to better understand the structure, processes and functions of these ecosystems, aiming at ecological restoration (Santana et al., 2004; Martins et al., 2015). Natural regeneration is an efficient ecological indicator of ecosystem conservation, contributing to the understanding of forest dynamics, and the nucleation effect by colonizing species in ecological restoration (Souto \& Boeger, 2011).

Natural regeneration assists biodiversity restoration in anthropogenic environments, initiating the connection between segregated landscapes through plant-animal interaction (Birch et al., 2010). Natural regeneration has a low cost due to the lower level of human intervention, which is an important characteristic to increase large-scale reforestation (Brancalion et al., 2012; Martins, 2013). In addition, regeneration monitoring within conservation units is crucial when elaborating necessary strategies and actions (Pivello, 2011).

Although important, there are few studies analyzing the structure and composition of natural regeneration, mainly due to difficulties in measurement and identification. Considering the current fragmentation of the Seasonal Forest, the present work aimed to characterize the regenerative potential in an area with a recent history of anthropic disturbance, in the Quarta Colônia State Park (PEQC), in order to obtain information on floristic and phytosociological composition to support future strategies of forest restoration.

\section{MATERIAL AND METHODS}

\subsection{Characterization of the study area}

The study was carried out in a fragment of Seasonal Forest located in the $P E Q C$, in the central region of RS. The region is located between the Serra Geral slope and the Peripheral Depression, in the border zone between the Atlantic Forest Biome and the Pampa Biome, constituting an important ecotonal transition zone.

The climate is "Cfa" according to the Köppen classification, humid subtropical with no dry season, an average annual temperature of $22^{\circ} \mathrm{C}$, rainfall varying between 1300 and $1800 \mathrm{~mm} /$ year $^{-1}$, with higher values recorded in the colder season (Alvares et al., 2013).

The study site comprises a forest fragment altered by anthropic actions prior to the installation of the Park, which resulted in clearings of herbaceous and semi-shrub vegetation, predominantly Poaceae, Asteraceae as Bacharis crispa Spring and Campuloclinium macrocephalum (Less.) DC. Although not a proper ciliary forest, the site is part of the riparian Jacuí river influence domain.

\subsection{Sampling the data}

A total of 256 sample units of $2 \times 2 \mathrm{~m}$ were installed in 2011, totaling $1024 \mathrm{~m}^{2}$ of sample area. The plots were distributed by stratification (Felfili et al., 2011), comprising all individuals with height $\geq 30 \mathrm{~cm}$ and collection diameter $\leq 1 \mathrm{~cm}$. Botanical identification was based on the species level, according to the Angiosperm Phylogeny Group IV botanical system (APG IV, 2016). The unidentified botanical material was collected for later identification in the Forest Herbarium of the Forest Science Department (HDCF) of the Federal University of Santa Maria (UFSM).

Phytosociological parameters of absolute (AF) and relative (RF) frequency, as well as absolute (AD) and relative (RD) density were measured (Finol, 1971). Next, the ecological Shannon diversity $\left(\mathrm{H}^{\prime}\right)$ index and Pielou Evenness (J) index (Brower \& Zar, 1984) were calculated to characterize the horizontal structure of the fragment.

\subsection{Data analysis}

Data were submitted to multivariate analysis by cluster analysis by Twinspan (Two Way Indicator Species) and Principal Component Analysis (PCA).

The species were grouped by their environmental similarities and/or dissimilarities, using agglomerative hierarchical grouping analysis. For this, we used the Euclidean distance as a measure of similarity or dissimilarity among the species through Statistica 7.0 software. 
The analysis by Twinspan was done through PC-Ord software (McCune \& Mefford, 1997) to group the study plots, using density of the species according to density by plots. Distribution of the eigenvalues was considered to be relevant when eigenvalues were $\geq 0.30$ (30\% variance) (Kent \& Coker, 1992; Felfili et al., 2007). For the analysis, the standard abundance cut-off level of the PC-ORD program was used (Felfili et al., 2007). Species with less than five individuals were discarded from this analysis, as proposed by Narvaes et al. (2008). To order the species in a system of axes, an ACP was performed through CANOCO version 4.5 software (Ter Braak \& Smilauer, 1998), considering species with a total number of individuals greater than 10 .

\section{RESULTS AND DISCUSSION}

\subsection{Floristics and horizontal structure}

There were 3021 regenerants distributed in 51 species and 26 botanical families, with Lauraceae and Meliaceae (six species), and Myrtaceae (four species) being the most representative. Lauraceae and Myrtaceae are among the most expressive families in the Seasonal Forest (Brito \& Carvalho, 2014; Horn Kunz \& Martins, 2014; Fávero et al., 2015).

Allophylus edulis showed the highest $\mathrm{AD}$ (5186 ind. Ha-1) and AF values (63.28\%), occurring in 162 of the 256 evaluated subplots. A. edulis presents large seed production, widely dispersed by fauna, fast growth and good regeneration capacity in different types of soil (Abreu et al., 2005). In addition, it does not require fertile soils for development (Almeida-Scabbia et al., 2011). This species is indicated for the recovery of degraded ecosystems, mainly in the surroundings of watercourses (Umeo et al., 2011).

In relation to the floristic diversity of the fragment, an $\mathrm{H}$ 'index of 2.78 and a J' of 0.66 was obtained, which can be considered high for an area in restoration. This suggests that the establishment of the regeneration species in the environment. For regeneration of the same typology, an $\mathrm{H}$ 'of 1.69 was found by the Continuous Forest Inventory of Rio Grande do Sul (Rio Grande do Sul, 2002). Also for Seasonal Forest in the Central Depression of RS, Sccoti et al. (2011) found an $\mathrm{H}$ 'of 2.38 and a J' of 0.61 , evaluating a height interval $\geq 30 \mathrm{~cm}$ and $\mathrm{DAP}<1 \mathrm{~cm}$.
The regeneration expression found is possibly due to the proximity to the Plategrass slopes of Riograndense, where the submontane and montane formations of the Seasonal Forest are present. These areas have remained more conserved due to the high slope, and now form a natural continuum, which can act as a source of propagules, even for the flat positions of the Jacuí river valley.

\subsection{Hierarchical grouping analysis}

The exotic Ligustrum lucidum species showed the greatest dissimilarity compared to the other species, uniting with species of other groups at a distance of approximately 74 (Figure 1).

The presence of invasive species within conservation units is contrary to the main objective of creating these areas, which is to preserve natural ecosystems of great ecological relevance (Brasil, 2000). Biological invasion gradually eliminates native species causing an imbalanced ecosystem and often with irreversible consequences. With aggressive and invasive characteristic, L. lucidum competes with the native vegetation regeneration, and is able to prevent the growth and even to suppress local species. Working in the same area of study, Hummel et al. (2014) observed that the species is exerting great pressure on the fragment due to the increasing number of regenerants, which represents direct competition for resources with native species. In Argentina, Lichstein et al. (2004) showed that $L$. lucidum dominance limits the recruitment of native seedlings.

In addition, the history of disturbances through which the studied area passes confers a significant fragility to the environment. Hoyos et al. (2010) confirm the rapid spread of L. lucidum in deforested areas, currently in the process of secondary succession.

(L.divar = Luehea divaricata Mart. \& Zucc.; A.salig = Aiouea saligna Meisn.; C.ig $=$ Celtis iguanaea (Jacq.) Sarg.; H.apicul = Helietta apiculata Benth.; S.bompl $=$ Sorocea bonplandii (Baill.) W.C. Burger, Lanjouw \& Boer; E.rostrif = Eugenia rostrifolia D.Legrand; Rubus = Rubus sp.; G.urug = Guettarda uruguensis Cham. \& Schltdl.; I.vera = Inga vera Willd.; M.tinctor $=$ Maclura tinctoria $($ L.) Don ex Steud.; P.aduncun $=$ Piper aduncum L.; T.catigua $=$ Trichilia catigua A. Juss.; Vassobia = Vassobia breviflora (Sendtn.) Hunz; P.cattl = Psidium cattleianum Sabine; 


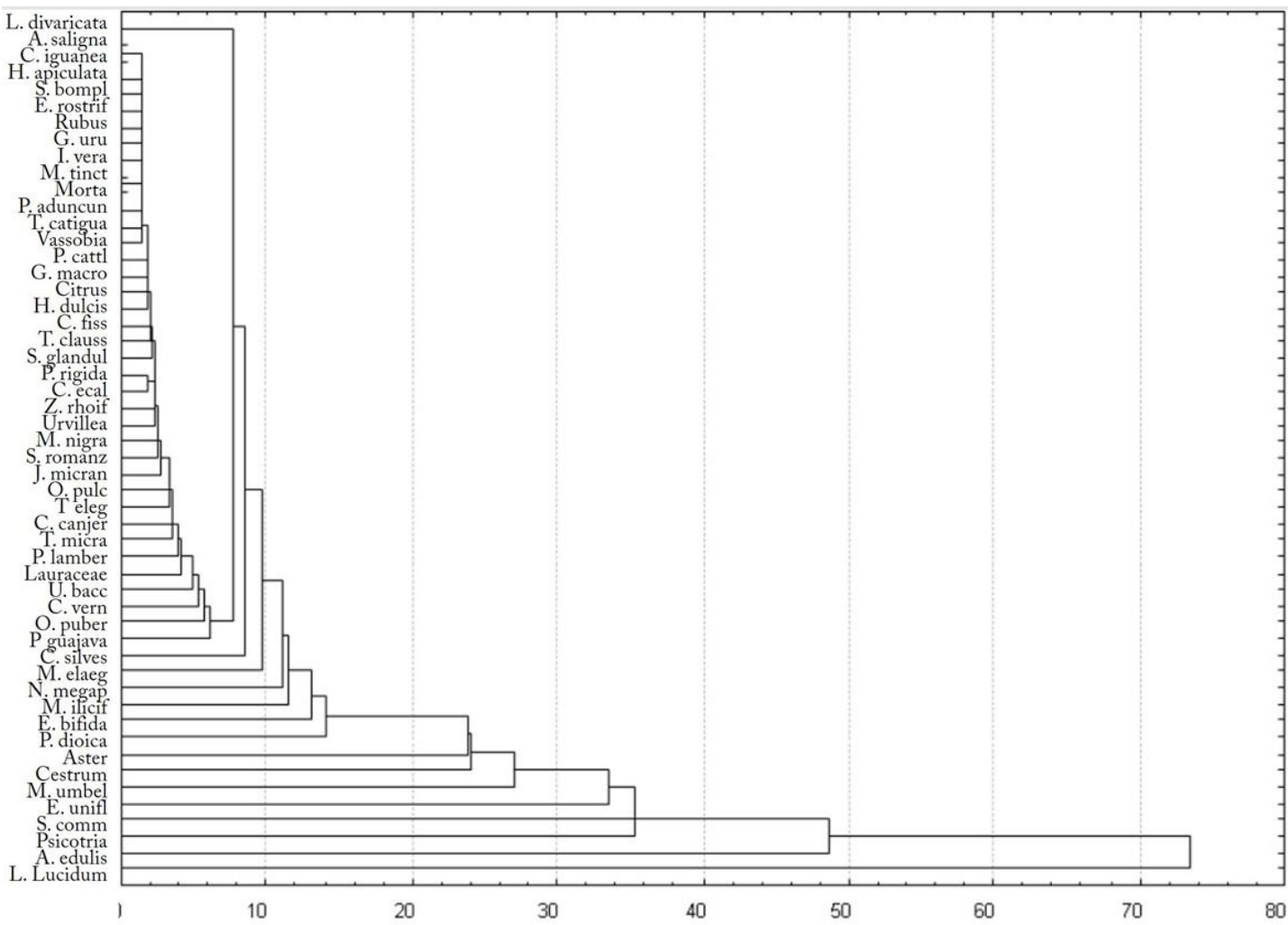

Figure 1. Hierarchical clustering analysis of arboreal and shrub species present in the regeneration stage of the Seasonal Forest, Rio Grande do Sul.

G.macrop = Guarea macrophylla Vahl; Citurs = Citrus sp.; H.dulcis = Hovenia dulcis Thunb.; C.fiss $=$ Cedrela fissilis Vell.; T.claus $=$ Trichilia claussenii C.DC.; S.glandul = Sapium glandulosum (L.) Morong; P.rigida $=$ Parapiptadenia rigida $($ Benth.) Brenan; C.ecal = Cordia e calyculata Vell.; Z.rhoif $=$ Zanthoxylum rhoifolium Lam.; Urvillea = Urvillea uniloba Radlk.; M.nigra = Morus nigra L.; S.romanz = Syagrus romanzoffiana (Cham.) Glassman; J.micran = Jacaranda micrantha Cham.; O.pulc $=$ Ocotea pulchella (Nees) Mez.; T.eleg $=$ Trichilia elegans $\mathrm{A}$. Juss.; .canjer $=$ Cabralea canjerana (Vell.) Mart.; T.micra = Trema micrantha (L.) Blume; LauraceaeNI =Lauraceae não identificada; U.bacc $=$ Urerabaccifera $($ L. $)$ Gaudich.; C.vern $=$ Cupaniavernalis Cambess.; O.puber $=$ Ocotea puberula (Rich.) Nees; P.guajava $=$ Psidium guajava L.; C.silves = Casearia sylvestris Sw.; M.elaeg = Matayba elaeagnoides Radlk.; N.megap = Nectandra megapotamica (Spreng.) Mez; M.ilicif = Maytenus ilicifolia Schwacke; E.bifida = Escallonia bifida Link \& Otto; P.dioica $=$ Phytolacca dioica L.; Aster = Asteraceae; Cestrum = Cestrum sp.;
M.umbel = Myrsine umbellata Mart.; E.unifl = Eugenia uniflora L.; S.comm= Gymnanthes klotzschiana (Baill.) L.B. Sm. \& Downs; Psicotria = Psychotria myriantha Müll. Arg; A.edulis =Allophylus edulis (A. St.-Hil., Cambess. \& A. Juss.) Radlk.; L.lucidum = Ligustrum lucidum W.T.Aiton).

Psychotria myriantha and Gymnanthes klotzschiana joined at a distance of approximately 35 with most other species, and at a distance of 48 with A. edulis (Figure 1).

A. edulis and G. klotzschiana present an important role in the return of the fauna with the greater yield of fruits, as well as species of the Psychotria genus, which are considered important feeding sources for the fauna of both pollinators and dispersers (Teixeira \& Machado, 2004). The presence of native pioneer species and initial secondary species that are attractive to the fauna (Rodrigues \& Gandolfi, 2000) is essential in order to reconstruct frugivorous-plant interactions in the restoration process. They play a key role as diversity generators and maintainers, in addition to 
contributing to the genetic exchange with the remnants of the environment.

We also observed the formation of a large group composed of species that showed low occurrence in regeneration (Table 1), constituting linkage groups between Luehea divaricata and Psidium guajava, clearly separated from a second set formed by the most abundant species. This intermediate cluster had a common characteristic of low frequency in the regeneration.

L. divaricata presented low occurrence, being observed in plots with greater degree of hydromorphy.
According to Reitz et al. (1983), the species prefers moist soils.

On the other hand, P. guajava was only observed in some subplots of the sample. Because it is an invasive species with fruits that are very appreciated by the fauna, few matrices can give rise to several regenerants, competing with the development of the native vegetation. P. guajava prefers areas of agriculture and disturbed areas, soils with good humidity, and places with more light like forest edges. It exerts great impact on the native flora due to the shading that it causes in the dominated areas (Instituto Hórus, 2017).

Table 1. Low occurrence species in the regeneration stage of the Seasonal Forest, viewed by hierarchical clustering analysis.

\begin{tabular}{|c|c|c|c|}
\hline Scientific Name & Popular Name & Family & Habitat \\
\hline Aiouea saligna Meisn. & Canela-vermelha & Lauraceae & Tree \\
\hline Cabralea canjerana (Vell.) Mart. & Canjerana & Meliaceae & Tree \\
\hline Cedrela fissilis Vell. & Cedro & Meliaceae & Tree \\
\hline Citrus sp. & Laranjeira & Rutaceae & Tree \\
\hline Cordia ecalyculata Vell. & Louro-mole & Boraginaceae & Tree \\
\hline Cupania vernalis Cambess & Camboatá-vermelho & Sapindaceae & Tree \\
\hline Eugenia rostrifolia D.Legrand & Batinga-vermelha & Myrtaceae & Tree \\
\hline Guarea macrophylla Vahl. & Catiguá-morcego & Meliaceae & Shrubs \\
\hline Guettarda uruguensis Cham. \& Schltdl. & Veludinho & Rubiaceae & Saplings \\
\hline Helietta apiculata Benth. & Canela-de-veado & Rutaceae & Tree \\
\hline Hovenia dulcis Thunb. & Uva-do-Japão & Rhamnaceae & Tree \\
\hline Inga vera Willd. & Ingá & Fabaceae & Tree \\
\hline $\begin{array}{l}\text { Jacaranda micrantha Cham. } \\
\text { Luehea divaricata Mart. \& Zucc. }\end{array}$ & $\begin{array}{c}\text { Caroba } \\
\text { Açoita-cavalo }\end{array}$ & $\begin{array}{l}\text { Bignoniaceae } \\
\text { Malvaceae }\end{array}$ & $\begin{array}{l}\text { Tree } \\
\text { Tree }\end{array}$ \\
\hline Maclura tinctoria (L.) Don ex Steud & Tajuba & Moraceae & Tree \\
\hline Morus nigra L. & Amora-preta & Moraceae & Tree \\
\hline Ocotea pulchella (Nees \& Mart.) Mez & Canela-do-brejo & Lauraceae & Tree \\
\hline Parapiptadenia rigida (Benth.) Brenan & Angico-vermelho & Fabaceae & Tree \\
\hline Piper aduncum L. & Matico & Piperaceae & Saplings \\
\hline Psidium cattleianum Afzel. ex Sabine & Araçá & Myrtaceae & Tree \\
\hline Psidium guajava L. & Goiaba & Myrtaceae & Tree \\
\hline Rubus sp. & Framboesa & Rosaceae & Saplings \\
\hline Sapium glandulosum (L.) Morong & Pau-leiteiro & Euphorbiaceae & Tree \\
\hline $\begin{array}{l}\text { Sorocea bonplandii (Baill.) W.C. Burger, } \\
\text { Lanjow \& Boer }\end{array}$ & Cincho & Moraceae & Shrubs \\
\hline Syagrus romanzoffiana (Cham.) Glassman & Jerivá & Arecaceae & Palm tree \\
\hline Trema micrantha (L.) Blume. & Grandiúva & Cannabaceae & Tree \\
\hline Trichilia catigua A. Juss. & Catiguá & Meliaceae & Shrubs \\
\hline Trichilia claussenii C.DC. & Catiguá-vermelho & Meliaceae & Tree \\
\hline Trichilia elegans A. Juss & Pau-de-ervilha & Meliaceae & Shrubs \\
\hline Urera baccifera (L.) Gaudich. ex Wedd. & Urtigão & Urticaceae & Saplings \\
\hline Urvillea uniloba Radlk. & Cipó-timbó & Sapindaceae & Vines \\
\hline Vassobia breviflora (Sendtn.) Hunz. & Esporão-de-galo & Solanaceae & Shrubs \\
\hline Zanthoxylum rhoifolium Lam. & Mamica-de-cadela & Rutaceae & Tree \\
\hline
\end{tabular}




\subsection{Floristic groups}

We formed two floristic groups (Figure 2). The first division separated the plots into two groups with an eigenvalue of 0.4430 . The left group had the most plots and the right group had 14 plots $(97,140,148$, $159,170,187,195,206,212,223,224,227,230$ and 242). The latter formed Group 1, with Asteraceae as an indicator species, and Eupatorium macrocephalum as the main representative species. In this group, the Asteraceae family was classified as indicative and preferential in 14 plots. Asteraceae showed aggression in colonization, especially in disturbed areas (Hattori \& Nakajima, 2008; Ferreira et al., 2001). According to Chazdon (2008), grasses, herbaceous plants and shrubs dominate recently abandoned areas, but decline in abundance as the forest canopy closes and reduces the availability of light.

The left group presented G. klotzschiana, Eugenia uniflora, and Myrsine umbellata as indicator species, classified as pioneers to early secondary (Carvalho, 2003). Pioneer species play a large role in this type of environment because they improve soil quality by producing biomass, improving compaction, interacting with soil fauna, and creating suitable conditions for the recruitment of late succession species (Rocha et al., 2016). G. klotzschiana, Nectandra megapotamica, E. uniflora and A. edulis are the preferred species. In a study carried out in the same forest formation in the Biological Reserve of Ibicuí-Mirim, central region of RS, Scipioni et al. (2011) found greater abundance of G. klotzschiana and A. edulis associated to areas near water courses, and N. megapotamica associated to the Neosols.

G. klotzschiana presented 302 individuals, which corresponds to the density of $2949 \mathrm{ind}^{\text {. ha }}{ }^{-1}$. With similar characteristics, E. uniflora appears with 304 individuals (2969 ind. ha ${ }^{-1}$ ) and M. umbellata with 84 individuals (1836 ind. ha- ${ }^{-1}$.

The highest number of G. klotzschiana individuals can be related to the fruiting of the species. According to Reitz et al. (1983), it blooms during most of the year, producing a moderate amount of seeds and propagules in regeneration.

For the frequency of species in the area, we observed that Group 1 occurred in more than half of the sample

$1^{\circ}$ division Eigenvalue: 0,4430

$\mathrm{S} 2, \mathrm{~S} 3, \mathrm{~S} 4, \mathrm{~S} 5, \mathrm{~S} 6, \mathrm{~S} 8, \mathrm{~S} 11, \mathrm{~S} 12, \mathrm{~S} 14, \mathrm{~S} 16, \mathrm{~S} 17, \mathrm{~S} 18, \mathrm{~S} 19, \mathrm{~S} 21, \mathrm{~S} 22$, S23, S24, S25, S28, S29, S30, S31, S32, S33, S34, S35, S36, S37, $\mathrm{S} 38, \mathrm{~S} 39, \mathrm{~S} 40, \mathrm{~S} 41, \mathrm{~S} 42, \mathrm{~S} 43, \mathrm{~S} 45, \mathrm{~S} 46, \mathrm{~S} 47, \mathrm{~S} 48, \mathrm{~S} 49, \mathrm{~S} 50, \mathrm{~S} 51$, S54, S60, S62, S65, S66, S67, S68, S69, S70, S71, S72, S74, S75, S76, S78, S79, S81, S83, S89, S91, S93, S94, S95, S96, S99, S104, S106, S107, S108, S110, S111, S114, S115, S116, S118, S119, S120, S121, S122, S124, S128, S129, S130, S131, S132, S135, S138, S139, S143, S144, S145, S147, S151, S153, S154, S155, S156, S157, S161, S165, S168, S169, S171, S173, S174, S175, S177, S185, S186, S188, S192, S197, S198, S199, S200, S202, S210, S211, S213, S216, S217, S219, S221, S225, S226, S228, S239, S240, S241, S243, S244, S247, S248, S250, S251, S252, S254, S255, S256.

Indicator species: G. Klotz; E. unif, M. umbel

\begin{tabular}{l|l}
$2^{\circ}$ division & Eigenvalue: 0,4225 \\
\end{tabular}

S2, S3, S4, S5, S6, S8, S11, S12, S14, S16, S17, S18, S19, S21, S22, S23, S24, S25, S28, S29, S30, S31, S32, S33, S34, S35, S36, S37, S38, S39, S40, S41, S42, S43, S45, S46, S47, S48, S49, S50, S51, S54, S62, S65, S66, S67, S68, S69, S70, S71, S72, S74, S75, S76, S78, S79, S93, S94, S95, S96, S114, S115, S116, S119, S120, S121, S122, S124, S128, S143, S147, S151, S157, S168, S169, S175, S177, S192.

Indicator species:

E. unifl, M. elaeg, M. ilicif, G. klotz

\section{Group 1}

S97, S140, S148, S159, S170, S187, S195, S206, S212, S223, S224, S230, S242.

Indicator species: Aster

Figure 2. Grouping Analysis (Twinspan) of arboreal and shrub species in the regeneration stage of the Seasonal Forest. 
plots. G. klotzschiana presented an AF of $42.19 \%$, E. uniflora of $43.36 \%$ and M. umbellata of $32.81 \%$.

The character of these species can be explained by their ecological features, which show that they prefer riparian environments, in addition to being adapted to water saturation in prolonged periods (Giehl et al., 2007). According to Araujo et al. (2004) and Budke et al. (2004), G. klotzschiana occurs naturally in forests along rivers and tends to form clusters. E. uniflora has a preference for moist soils and $M$. umbellata adapts to a wide range of edaphic conditions.

Abbreviations: (G. klotz = Gymnanthes klotzschiana, E.unifl = Eugenia uniflora, M.umbel = Myrsine umbellata, N.megap = Nectandra megapotamica, A.edulis =Allophylus edulis, Aster = Asteraceae, M.ilicif = Maytenus ilicifolia, M.elaeg = Matayba elaeagnoides, C.silves = Casearia sylvestris, P.myrti = Prunus myrtifolia $)$, P.aduncun =Piper aduncum .

The second division generated an eigenvalue of 0.4225 and divided the plots into two groups. The left group formed Group 2. In this group, the indicator species are G. klotzschiana, Matayba elaeagnoides, Maytenus ilicifolia and E. uniflora, and the preferred species are G. klotzschiana, M. elaeagnoides, Casearia sylvestris,
M. ilicifolia, Prunus myrtifolia, Piper aduncum and E. uniflora. Group 3 indicator species show developmental characteristics related to the presence of moist soils (M. elaeagnoides and E. uniflora) or occurrence in alluvial plains (G. klotzschiana and M. ilicifolia) (Carvalho, 2008).

\subsection{Principal component analysis}

The ACP determined three main components, representing a cumulative variance percentage of $63.69 \%$ up to the third axis, distributed in $36.62 \%$, $14.89 \%$ and $12.18 \%$, for the first, second and third axes, respectively. The relatively low variance values work as an indicator of the environment heterogeneity, typical of riparian vegetation, which is considered one of the most heterogeneous environments in terms of forest typology (Rodrigues \& Nave, 2009), and express the discontinuity of vegetation in the area.

As in the hierarchical grouping analysis, the ACP highlighted the behavior of L. lucidum, which presented the highest eigenvalue in the first axis (13.701), widely distancing from the other species forming a separate group, and separated from those by axis II (Figure 3 ).

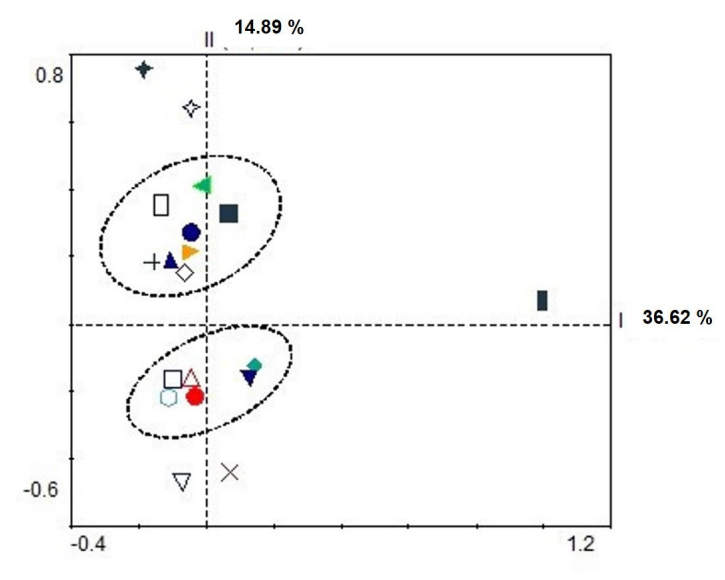

\begin{tabular}{|c|c|}
\hline $\begin{array}{l}\text { 7llophylus edulis } \\
\times \text { Asteraceae } \\
\text { Cabralea canjerana } \\
\text { A Casearia sylvestris } \\
\text { Eugenia uniflora } \\
\text { - Lauraceae } \\
\text { - Ligustrum lucidum } \\
\text { प Luehea divaricata } \\
\text { Matayba elaeagnoides } \\
\text { पMaytenus ilicifolia }\end{array}$ & $\begin{array}{l}\text { + Myrsine umbelatta } \\
\text { Nectandra megapotamica } \\
\text { - Ocotea puberula } \\
\diamond \text { Piper aduncun } \\
\text { - Prunus myrtifolia } \\
\text { Psychotria myriantha } \\
\text { - Gymnanthes klotzchiana } \\
\triangle \text { Trichilia elecans } \\
\text { Zarthoxylum rhoifolium }\end{array}$ \\
\hline
\end{tabular}

Figure 3. Principal Components Analysis Diagram of forest species with more than ten individuals in the regeneration stage of the Seasonal Forest. 
The majority of the species presented higher eigenvalues in the second axis, with L. divarticata, Asteraceae, N. megapotamica, A. edulis, P. aduncum and $P$. myriantha forming a group separated by axis I, presenting A. edulis with an eigenvalue of 11.983. The third axis highlighted the behavior of G. klotzschiana and E. uniflora with eigenvalues of 8.483 and 7.783 , respectively.

The appropriate restoration strategy for each area depends on the level of degradation and the desired rate of recovery (Aide et al., 2000). Natural regeneration was confirmed as an efficient strategy for the study site, considering the existence of propagule sources in the environment and the level of local resilience that offers good environmental conditions for the development of the species and expression of diversity.

However, the strong presence of invasive species in regeneration, especially L. lucidum, is a worrying factor and should be prioritized in control strategies, mainly because it is a conservation unit. When performed in the initial stages of invasion, the control presents lower costs and greater operational ease, since it does not require the future slaughter of adult individuals.

\section{CONCLUSION}

1. Ligustrum lucidum was the main biological invader in the regeneration phase, and presents a real risk for the maintenance of native species in the area due to the obtained indices;

2. Gymnanthes klotzschiana, Eugenia uniflora and Myrsine umbellata are the main indicators of the riparian environment in the study area, and may be recommended for restoration actions in the region;

4. Allophylus edulis plays an important role in the regeneration of the area due to its abundance and the potential for avifauna attraction, which also makes it a facilitator species in the restoration process;

5. Within the class range used, this analysis efficiently highlighted the biological invasion problem, and demonstrated the importance of regeneration studies and not only the arboreal stratum for forest recovery and conservation projects, but especially when dealing with conservation units.

\section{ACKNOWLEDGEMENTS}

The authors thank the National Council of Scientific and Technological Development $(\mathrm{CNPq})$ and the State Environment Secretary of Rio Grande do Sul state (SEMA).

\section{SUBMISSION STATUS}

Received: 31 jul., 2017

Accepted: 14 feb., 2018

\section{CORRESPONDENCE TO}

\section{Ana Paula Moreira Rovedder}

Núcleo de Estudos e Pesquisas em Recuperação de Áreas Degradadas, Universidade Federal de Santa Maria, Avenida Roraima, 1000, CEP 97105900 , Bairro Camobi, Santa Maria, RS, Brasil e-mail: anarovedder@gmail.com

\section{FINANCIAL SUPPORT}

Conselho Nacional de Desenvolvimento Científico e Tecnológico.

\section{REFERENCES}

Abreu DCA, Kuniyoshi YS, Nogueira AC, Medeiros ACS. Caracterização morfológica de frutos, sementes e germinação de Allophylus edulis (St.-Hil.) Radlk. (Sapindaceae). Revista Brasileira de Sementes 2005; 27(2): 59-66. http://dx.doi. org/10.1590/S0101-31222005000200009.

Aide TM, Zimmerman JK, Pascarella JB, Rivera L \& Marcano-vega H. Forest regeneration in a chronosequence of tropical abandoned pastures: implications for restoration ecology. Restoration Ecology 2000; 8(4):328-338.

Almeida-Scabbia RJ, Schlittler FHM, Cesar O, Monteiro R, Gomes EPC, Neto SR. Características físico-químicas do solo e distribuição de espécies arbóreas em um trecho de cuesta basáltica, Analândia, SP, Brasil. Revista Brasileira de Biociências 2011; 9(3): 322-331.

Alvares CA, Stape JL, Sentelhas PC, Moraes Gonçalves JL, Sparovek G. Köppen's climate classification map for Brazil. Meteorologische Zeitschrift 2013; 22(6): 711-728. http://dx.doi.org/10.1127/0941-2948/2013/0507.

Angiosperm Phylogeny Group. An update of the Angiosperm Phylogeny Group classification for the orders and families of flowering plants: APG IV. Botanical Journal of the Linnaean Society 2016; 181:1-20. 
Araujo MM, Longhi SJ, Brena DA, Barros PLC, Franco S. Análise de agrupamento da vegetação de um fragmento de Floresta Estacional Decidual Aluvial, Cachoeira do Sul, RS, Brasil. Ciência Florestal 2004; 14(1): 133-147. http://dx.doi.org/10.5902/198050981789.

Birch JC, Newton AC, Aquino CA, Cantarello E, Echeverría C, Kitzberger $\mathrm{T}$ et al. Cost-effectiveness of dryland forest restoration evaluated by spatial analysis of ecosystem services. Proceedings of the National Academy of Sciences of the United States of America 2010; 107(50): 21925-21930. http://dx.doi.org/10.1073/pnas.1003369107. PMid:21106761.

Brancalion PHS, Viani RAG, Rodrigues RR, Gandolfi S. Avaliação e monitoramento de áreas em processo de restauração. In: Martins SV editores. Restauração ecológica de ecossistemas degradados. Viçosa: Editora UFV; 2012.

Brasil. Ministério do Meio Ambiente. Lei $n^{\circ}$ 9.985, de 18 de julho de 2000. Regulamenta o art. 225, $1^{\circ}$, incisos I, II, III e VII da Constituição Federal, institui o Sistema Nacional de Unidades de Conservação da Natureza e dá outras providências. Diário Oficial da República Federativa do Brasil, Brasília, DF (2000 jul.).

Brito PS, Carvalho FA. Estrutura e diversidade arbórea da Floresta Estacional Semidecidual secundária no Jardim Botânico da Universidade Federal de Juiz de Fora. Rodriguésia 2014; 65(4): 817-830. http://dx.doi. org/10.1590/2175-7860201465402.

Brower JE, Zar JH. Field and laboratory methods for general ecology. 2. ed. Iowa: Brown Publishers; 1984.

Budke JC, Giehl ELH, Athayde EA, Eisinger SM, Záchia RA. Florística e fitossociologia do componente arbóreo de uma floresta ribeirinha, arroio Passo das Tropas, Santa Maria, RS, Brasil. Acta Botanica Brasílica 2004; 18(3): 581589. http://dx.doi.org/10.1590/S0102-33062004000300016.

Carvalho PER. Espécies arbóreas brasileiras. Vol. 1. Colombo: Embrapa Florestas; 2003.

Carvalho PER. Espécies arbóreas brasileiras: recomendações silviculturais, potencialidade e uso da madeira. Brasília: Embrapa Informações Tecnológicas; Colombo: Embrapa Florestas; 2008.

Chazdon RL. Beyond deforestation: restoring forests and ecosystem services on degraded lands. Science 2008; 320(5882): 1458-1460. http://dx.doi.org/10.1126/ science.1155365. PMid:18556551.

Fávero AA, Costa MP, Figueira M, Andriollo DD, Longhi SJ. Distribuição de abundância de espécies da comunidade arbórea do topo de um morro na floresta estacional subtropical. Ciência Rural 2015; 45(5): 806-813. http:// dx.doi.org/10.1590/0103-8478cr20121238.

Felfili JM, Carvalho FA, Libano AM, Venturoli F, Pereira BAS. Análise multivariada em estudos de vegetação. Brasília: Universidade de Brasília, Departamento de Engenharia Florestal; 2007.
Felfili JM, Roitman I, Medeiros MM, Sanchez M. Procedimentos e métodos de amostragem de vegetação. In: Felfili JM, Eisenlohr PV, Melo MMRF, Andrade LA, Meira Neto JAA, editores. Fitossociologia no Brasil: métodos e estudos de caso. Viçosa: Ed. UFV; 2011.

Ferreira AG, Cassol B, Rosa SGT, Silveira TS, Stival AL, Silva AA. Germinação de sementes de Asteraceae nativas do Rio Grande do Sul, Brasil. Acta Botanica Brasílica 2001; 15(2): 231-242. http://dx.doi.org/10.1590/S010233062001000200009 .

Finol H. Nuevos parametros a considerarse en el análisis estructural de las selvas virgenes tropicales. Revista Forestal Venezolana 1971; 14(21): 29-42.

Fundação SOS Mata Atlântica - SOS Mata Atlântica, Instituto Nacional de Pesquisas Espaciais - INPE. Atlas dos Remanescentes Florestais da Mata Atlântica - Período 2013-2014. São Paulo: Fundação SOS Mata Atlântica; 2015.

Giehl ELH, Athayde EA, Budke JC, Gesing JPA, Einsiger SM, Canto-Dorow TS. Espectro e distribuição vertical das estratégias de dispersão de diásporos do componente arbóreo em uma Floresta Estacional no Sul do Brasil. Acta Botanica Brasílica 2007; 21(1): 137-145. http://dx.doi. org/10.1590/S0102-33062007000100013.

Hattori EKO, Nakajima JN. A família Asteraceae na estação de pesquisa e desenvolvimento ambiental Galheiros, Perdizes. Minas Gerais, Brasil. Rodriguésia 2008; 59(4): 687-749. http://dx.doi.org/10.1590/2175-7860200859405.

Horn Kunz S, Martins SV. Regeneração natural de floresta estacional semidecidual em diferentes estágios sucessionais (Zona da Mata, MG, Brasil). Floresta 2014; 44(1): 111-124. http://dx.doi.org/10.5380/rf.v44i1.30736.

Hoyos LE, Gavier-Pizarro GI, Kuemmerle T, Bucher EH, Radeloff VC, Tecco PA. Invasion of glossy privet (Ligustrum lucidum) and native forest loss in the Sierras Chicas of Córdoba, Argentina. Biological Invasions 2010; 12(9): 3261-3275. http://dx.doi.org/10.1007/s10530-010-9720-0.

Hummel RB, Coghetto F, Piazza EM, Toso LD, Dick G, Felker RM et al. análise preliminar da invasão biológica por Ligustrum lucidum W.T. Aiton em unidade de conservação no Rio Grande do Sul. Cadernos de Pesquisa 2014; 26(3): 14-26.

Lichstein JW, Grau HR, Aragón R. Recruitment limitation in secondary forests dominated by an exotic tree. Journal of Vegetation Science 2004; 15(6): 721-728. http://dx.doi. org/10.1111/j.1654-1103.2004.tb02314.x.

Instituto Brasileiro de Geografia e Estatística - IBGE. Manuais técnicos em geociências: manual técnico da vegetação brasileira. 2. ed. Rio de Janeiro; 2012.

Instituto Hórus. Base de dados de espécies exóticas invasoras [online]. Florianópolis: Instituto Hórus; 2017 [cited 2017 Mar 2]. Available from: www.institutohorus.org.br

Kent M, Coker P. Vegetation description and analysis. London: John Wiley \& Sons; 1992. 
Martins SV, Neto AM, Ribeiro TM. Uma abordagem sobre a diversidade e técnicas de restauração ecológica. In: Martins SV. Restauração ecológica de ecossistemas degradados. 2. ed. Viçosa: UFV; 2015.

Martins SV. Recuperação de áreas degradadas: Ações em áreas de preservação permanente, voçorocas, taludes rodoviários e de mineração. 3. ed. Viçosa: Aprenda Fácil; 2013.

McCune B, Mefford MJPC-ORD. Multivariate Analysis of Ecological Data, v.3.12. Oregon: MjM Software Design; 1997.

Narvaes I, Longhi SJ, Brena DA. Florística e classificação da regeneração natural em floresta ombrófila mista na floresta nacional de São Francisco de Paula, RS. Revista Ciência Florestal 2008; 18(2): 233-245.

Pivello VR. Invasões Biológicas no Cerrado Brasileiro: Efeitos da Introdução de Espécies Exóticas sobre a Biodiversidade. Ecologia Info 33 [online]. 2011 [cited 2018 jul 02]. Available from: Available from: http://ecologia. info/cerrado.htm

Reitz P, Klein, RM, Reis A. Projeto Madeira do Rio Grande do Sul. Itajaí: Herbário Barbosa Rodrigues; 1983.

Rio Grande do Sul. Governo do Estado. Secretária Estadual do Meio Ambiente. Inventário do Rio Grande do Sul [online]. Porto Alegre: FATEC/SEMA; 2002 [cited 2018 Jan 10]. Available from: http://w3.ufsm.br/ifcrs/frame.htm

Rocha GPE, Vieira DLM, Simon MF. Fast natural regeneration in abandoned pastures in southern Amazonia. Forest Ecology and Management 2016; 370: 93-101.

Rodrigues RR, Gandolfi S. Conceitos, tendências e ações para a recuperação de florestas ciliares. In: Rodrigues RR, Leitão-Filho HF, editores. Matas ciliares: conservação e recuperação. São Paulo: EDUSP/FAPESP; 2000.

Rodrigues RR, Nave AG. Heterogeneidade florística das matas ciliares. In: Rodrigues RR, Leitão Filho HF, editores. Matas ciliares: conservação e recuperação. São Paulo: Editora da Universidade de São Paulo: Fapesp; 2009.

Santana CAA, Lima CCD, Magalhães S. Estrutura horizontal e composição florística de três fragmentos secundários na cidade do Rio de Janeiro. Acta Scientiarum. Biological Sciences 2004; 26(4): 443-451. http://dx.doi.org/10.4025/ actascibiolsci.v26i4.1525.

Sccoti SV, Araujo MM, Wendler CF, Longhi SJ. Mecanismos de regeneração natural em remanescente de Floresta Estacional Decidual. Ciência Florestal 2011; 21(3): 459472. http://dx.doi.org/10.5902/198050983803.

Scipioni MC, Finger CAG, Cantarelli EB, Denardi L, Meyer EA. Fitossociologia em fragmento florestal no noroeste do estado do Rio Grande do Sul. Ciência Florestal 2011; 21(3): 409-419. http://dx.doi.org/10.5902/198050983799.

Souto MAG, Boeger MRT. Estrutura e composição do estrato de regeneração e vegetação associada de diferentes estádios sucessionais no leste do Paraná. Ciência Florestal 2011; 21(3): 393-406. http://dx.doi.org/10.5902/198050983798.

Teixeira LAG, Machado IC. Biologia da polinização e sistema reprodutivo de Psychotria barbiflora DC. (Rubiaceae). Acta Botanica Brasílica 2004; 18(4): 853-862. http://dx.doi.org/10.1590/S0102-33062004000400016.

Ter Braak CJF, Smilauer P. CANOCO reference manual and user's guide to Canoco for Windows: Software for canonical community ordination (version 4). New York: Microcomputer Power; 1998.

Umeo SH, Ito TM, Yokota ME, Romagnolo MB, Laverde A Jr. Avaliação das propriedades antioxidantes, anticolinesterásicas e citotóxicas dos frutos de Allophylus edulis (A.ST.-HIL. Cambess. \& A. Juss.) Radlk. (SAPINDACEAE). Arquivos Ciência Saúde 2011; 15(2): 167-171. 